\title{
13. Between New Caledonia and Papua New Guinea
}

COLIN FLLER AND PIERRE-YYES LE MEUR

In this concluding chapter, we return to the question posed in the introduction-the question of how to explain the similarities and differences in the relationship between large-scale mines and local-level politics in New Caledonia (NC) and Papua New Guinea (PNG), or in different parts of these two countries. The subtitle of this book (and the title of this chapter) could be read as a sign of our belief that the relationship between large-scale mines and local-level politics is one whose form and content mainly varies between countries or jurisdictions, largely as a result of differences in their political history and the current legal and policy frameworks in which the relationship is embedded. However, while there clearly are some points to be made on this score, the contributions to this volume also show that the relationship varies between projects and places as much as it does between countries, so there is no reason to assign a special kind of power to what we described (in Chapter 1) as the 'state corner' in our rectangular model of stakeholder relationships. Instead, we may conceive of the space 'between' NC and PNG as one that contains a number of different relationships between large-scale mines and locallevel politics whose variation can partly be understood in terms of the 'balance of power' between the four corners in that model, but partly also in terms of other dimensions of difference. 


\section{Between Version One}

Although the contributors to this volume have a good deal to say about political conflict, they have eschewed the well-worn concept of the 'resource curse' (Ross 2003) and the related question of whether political actors in mine-affected communities are motivated by 'greed or grievance' (Collier and Hoeffler 2004). Anthony Regan's review of the history of political conflict around the Panguna mine (Chapter 12) does not lead us to conclude that local political reactions to large-scale mining projects are generally more intense or more violent in PNG than they are in NC, and even if we had evidence to this effect, we could not readily link it to the extent of each country's economic dependence on the mining industry, nor to the motivations of political actors who belong to mine-affected communities. If it barely makes sense to say that large-scale mines are 'more political' in one country than in the other, then it might make more sense to argue that large-scale mining operations are not so much causes of political conflict as things or spaces that attract it, in which case the form and extent of conflict in each country needs to be considered as a sort of independent variable (Banks 2008).

We are also reluctant to conclude that variations in the relationship between large-scale mines and local-level politics can simply be explained by reference to the fact that PNG and NC represent or possess two different kinds of 'society' - say a 'post-colonial' one as opposed to a 'late colonial' or 'semi-colonial' one. In this respect, we agree with actor-network theorists who would say that this does not count as an explanation so much as a summary of what it is we are trying to explain (Latour 2005). To emphasise this point, we have used the noun 'society' in a very different way, to designate a recently and somewhat poorly assembled group of 'stakeholders' in our model of political relationships. The question then is whether the four groups of stakeholders in our model have been assembled in different ways in the two countries under discussion. On this score, it could be argued that the rectangular model is better 'fitted' to the politics of the large-scale mining industry in PNG than to its counterpart in NC because there is more power, or a group of more powerful actors, located in PNG's 'social corner', and less power, or a group of less powerful actors, located in PNG's 'state corner' (Chapter 9).

Of course, there is no escaping the significance of what Le Meur (Chapter 5) calls the 'meta-conflict' of settler colonialism in any account of what sets the two countries apart. All five of our chapters on NC deal 
with mine-affected communities that are primarily Kanak communities in a country (or territory) where Kanaks still account for a minority of the total population. In some respects, the political complexion of the mining industry in $\mathrm{NC}$ is more like that found in other countries where indigenous people are still subordinate to people of European descent than like that which obtains in the independent and 'indigenous' state of PNG. Even so, the fact that Kanaks account for roughly 40 per cent of NC's population explains why their leaders have been able to pursue the path of decolonisation and independence, rather than simply seek to advocate their rights as an indigenous minority.

Although PNG has its own colonial legacy, the Autonomous Region of Bougainville is the only part of the country where this legacy continues to cast a shadow across the politics of the mining industry, and that is because the Panguna mine was conceived and built as an Australian colonial enterprise. Even in nine decades of colonial rule, PNG never witnessed the wholesale expropriation of the native population, nor the creation of 'tribal reserves' of the kind established in NC, nor even the establishment of an effective system of indirect rule on the part of the colonial administration. And while PNG's achievement of national independence took place at the same time that Kanaks began to demand the right of self-determination, the slow process of decolonisation in NC has resulted in a form of local-level politics that is dominated by a deepening division between French and Kanak political institutions. Furthermore, this division has been complicated by a further split between those Kanak political institutions that were part of the colonial system of indirect rule and those that have since been created in response to the demand for self-determination (Chapters 4 and 6). The only parallel to be found in PNG's post-colonial form of local-level politics is the one between the laws inherited from Australia and those created to accommodate what the National Constitution nominates as 'Papua New Guinean forms of social, political and economic organisation'.

The key point about the power of the state in NC is that local (Caledonian) institutions are opposed to metropolitan (French) institutions at the same time that 'neotraditional' (Kanak) institutions are opposed to 'modern' (European) institutions (Demmer and Salomon 2017). This is less a form of 'hybridity' (Clements et al. 2007) than a sort of double duality that diminishes the power of 'the state as such' at the same time that it makes more space for the practice of local-level politics in the suspended moment of the Nouméa Agreement preceding the referendum on independence 
to be held in 2018 (Le Meur 2017). This should not lead us to think that there is any significant difference between the two countries in the number of roles (per capita or per project) that make up the political structure of the mining industry, but it does lead us to wonder if the practice of politics has escaped, avoided or even subverted the practice of government - or governmentality—in PNG's version of this structure to an extent that is not so evident in NC.

If this means that community actors in PNG now wield more power than their (indigenous) counterparts in NC, it also seems to be consistent with the observation that this power is exercised within a neotraditional political order that is rather more chaotic and contestable, mainly because the institution of chieftainship is less significant. However, it is hard to tell how much of this difference in the form of local-level politics is due to the impressions left by the colonial legacy, to the relative strength or weakness of contemporary state institutions, or to differences in pre-colonial 'political cultures' (Chapters 4, 8 and 9).

When it comes to the politics of the large-scale mining industry, what clearly does matter is that all large-scale mining operations in PNG have required the state's acquisition of large areas of customary land, whereas those in NC tend to exclude customary claims to the state land on which they are almost invariably located (Chapters 3 and 4). While this explains the difference in the power that community actors can exercise over the mining industry in their capacity as 'customary landowners', it also explains why community actors in both countries have been slow to represent themselves as 'indigenous peoples' whose land rights need to be reinforced by appeals to international norms. In the PNG case, political actors in all corners of our rectangular model seem to believe that the 'customary landowner' is already a more powerful character than any kind of indigenous person (Chapter 9). In the NC case, by contrast, the limits previously imposed on the extent of customary land rights seem to have discouraged Kanak political leaders from using such rights as the basis of their demand to exert greater control over the operation of the mining industry (Chapter 6), even though mining agreements have included a recognition that the original occupants of any land should take precedence over those who followed (and sometimes dispossessed) them (Chapters 3 and 4). 
If the 'ideology of landownership' therefore has much greater political weight in PNG than it has in NC, there is also a notable difference in the qualities and quantities of the 'benefit streams' that flow to mineaffected communities. This is not just a difference in the extent to which communities are entitled to compensation for the use of their customary land, but also a function of the fact that NC lacks any counterpart to the institutional machinery through which PNG's national government collects an output-based royalty from each large-scale mining project and then redistributes the whole of this income to different groups of political actors (including groups of customary landowners) within the province where the project is located. Furthermore, NC lacks any obvious counterpart to the policy by which PNG's national government obliges mining companies to make special efforts to train and employ the members of mine-affected communities. As a result, Kanak political leaders have laid a greater emphasis on what PNG's policy regime designates as 'equity benefits' and 'business development opportunities', which means that the distribution of shares in mining companies and their suppliers becomes a matter of paramount concern (Chapters 2 and 6). This type of benefit is also a matter of great concern in PNG, but the wider range and volume of 'landowner benefits' or 'community benefits' in PNG seems to have created more of a stimulus for the process that Glenn Banks and colleagues (in Chapter 7) call 'immanent development', and more of an incentive for the local beneficiaries to exclude 'outsiders' from their realm of entitlement (Chapter 11).

In one sense, this would suggest that PNG has a more intense form of identity politics, if the key political question is who counts as a landowner or community member in respect of any particular mining project. However, that question is clearly related to the intensity of local-level political contests over the distribution of material costs and benefits, and it could be argued that this type of contest is less intense in NC because there is less at stake. In that case, it would seem to follow that $\mathrm{NC}$ does not have a less intense form of identity politics, but a different form of identity politics-one that is more concerned with what we have called (in Chapter 1) the representational issue than the distributional issue, and more concerned with the establishment of a Kanak identity than a strictly local identity (Chapters 4 and 5).

These considerations lead us to wonder whether and how it makes sense to regard PNG and NC as countries located at different points along one or more historical trajectories, and if so, how it makes sense to regard PNG 
as a country that is more 'advanced' in the political construction of its mining industry, despite the enduring paradox of human poverty in the midst of mineral wealth (Filer et al. 2016). If PNG is more advanced in the process of decolonisation, and also more advanced in the double-sided process of modernisation and globalisation, how does the relationship between these different trajectories produce a national contrast in the relationship between large-scale mines and local-level politics?

Although we have postulated a general process of modernisation and globalisation within the large-scale mining industry, this should not be taken to mean that we subscribe to a version of 'modernisation theory' (or 'dependency theory') that would allow us to arrange our two countries or their component parts, including their mining enclaves, along a single path that leads to a single goal, whether that goal be conceived as a condition of 'modernity', 'development' or 'neoliberal governmentality'. As we pointed out in the introduction to this volume, the process has several different aspects that are not invariably found in combination with each other, and each of these has different political effects. We have not suggested that this process is one variant of an even more general process that has taken the same form over the same period of time in all other branches of the global capitalist economy. We have not even suggested that the process is permanent and irreversible in those places where its effects can be observed, since the mining industry is notorious for its booms and slumps, and one feature of the process we have described is that the mining industry now moves more rapidly from one location to another, often leaving desolation in its wake.

When we say that PNG contains a more 'advanced' form of the process, we partly refer to the extent of the gulf between multinational mining companies and mine-affected communities (Chapter 7), to the way in which representations of this gulf contributed to the 'enlightenment' of the global mining industry in the 1990s (Chapter 9), and to the role of international actors like the World Bank in attempting to repatriate the lessons of this enlightenment to the country from which they had been drawn (Filer et al. 2008). In all such respects, it could be said that $\mathrm{NC}$ was left behind for a while, even if it is now catching up with some of the trends, as new 'social' actors and political narratives have entered the mineral policy domain. The discourse of environmental protection, supported by non-governmental and community-based organisations, is an obvious case in point (Chapters 5 and 6), but this is only one part of the broader discourse of corporate social responsibility. 
We might also be tempted to argue that PNG's large-scale mining industry is also very modern because 'society' has as much weight as the state in building the metaphorical roads or bridges that connect big mining companies with groups of indigenous people or customary landowners. If we take that path, we might then say that mine-affected communities in $\mathrm{NC}$ are also 'state-affected communities' to an extent that is not true of PNG because the PNG Government is well known for its habit of disappearing from mine-affected areas once development agreements have been signed (Chapters 8 and 9). In that case, the political complexion of PNG's mining industry appears to possess a 'neoliberal' character that is not (yet) evident in NC, since the 'selective absence of the state' (Szablowski 2007) appears to have been the result of an ongoing transfer of power from state actors to both corporate and social actors. However, we also need to bear in mind that NC's oldest mining company (SLN) already held quasi-governmental powers before the emergence of neoliberal forms of governance or governmentality in the period since 1980 (Chapter 5).

If PNG and NC are still to be conceived as jurisdictions located at different points along a single historical trajectory, then this path may also be construed in terms of a shift from the social relations of employment to the social relations of compensation, so long as 'compensation' is understood to be something broader than compensation for the loss of customary land. The broader concept belongs to the general model of reflexive modernisation (Beck 1992), characterised by the double internalisation of risk as a social construct and a way of ordering material reality (Dean 2010). This form of 'risk society' is obviously connected with the practice of environmental (and social) impact and risk assessment and with norms of environmental (and social) justice (Dupuy 2002; Walker 2012). From this point of view, we may then proceed to ask whether the transformation of social relations as the subject of political action has still had somewhat different political effects in each of our two countries because of the manner in which the social relations of compensation have come to encompass the mining industry.

On this score, we would say that PNG acquired a resource-dependent economy in the process of dispensing with the legacy of colonial rule and, for this reason, the modernisation of the mining industry was encompassed by a national ideology - the ideology of landownershipthat served to intensify the social relations of compensation and extend their reach to parts of the country that were not directly affected by 
any large-scale mining operations (Filer 1997). In NC, by contrast, a 'traditional' large-scale mining industry already dominated the colonial economy at the time when PNG achieved its independence in 1975, and the process of modernisation did not begin to have political effects until PNG had already acquired its new national ideology. What happened instead is that the exercise of political control over the mining industry became the means by which representatives of the Kanak population have sought compensation, not for the loss of specific areas of customary land, but for the broader historical experience of dispossession and subordination under the French colonial regime. As a result, the political relationship between ideas of indigenous identity and environmental justice seems to have a very different complexion (Ali and Grewal 2006; Le Meur 2010). In this respect, the 'half-way house' would be the case of Bougainville, where a modern mine was established before PNG became an independent country, but then became a symbol of neocolonial dispossession for a new generation of secessionists whose actions were triggered by demands for environmental (and social) justice (Chapter 12).

\section{Between Version Two}

Once we think of Bougainville as a 'mineral province' that lies between PNG and NC in both a political and a geographical sense, we can immediately see that a comparison between two national jurisdictions is only one type of comparison that can be made when we seek to understand variations in the relationship between large-scale mines and local-level politics. In one political respect, Bougainville and $\mathrm{NC}$ have more in common with each other than either has with (the rest of) PNG, since both are 'partial countries' confronting the prospect of a referendum on independence, and Bougainvillean nationalism bears some comparison with Kanak nationalism as an ideology that plays out in the politics of the mining industry. But if we go one step further and think of Bougainville as one of several 'mineral provinces' in PNG, then the questions previously posed about the difference between two national jurisdictions, two sets of political institutions, or two historical trajectories, can be turned into questions about the difference between a larger number of smaller political entities and the mining operations that they have hosted.

As noted in the introduction to this volume, PNG is a much bigger country than NC, both in terms of the scales used by cartographers to measure surface areas and in terms of the size of their respective 
populations. The whole of the resident population of $\mathrm{NC}$ is of a similar order of magnitude to that of the Autonomous Region of Bougainville and to each of PNG's five provinces that currently host at least one large-scale mining project. While $\mathrm{NC}$ has been divided into three provinces, two of which can be counted as 'mineral provinces', one of them (North Province) has a much smaller population than the other one (South Province), comparable to the population of what officially counts as a 'district' in PNG. Yet there is no simple correlation between the size of a mineral province and the size or shape or scale of the mining operations located within it. In both of NC's mineral provinces, large-scale processing plants derive their raw material from mining operations that vary a good deal in their scale and location. This type of variation is not found in PNG's five mineral provinces, where each big mining project consists of a single processing plant that derives its raw material from a single mining operation. Yet these projects also vary in scale and location and impact, and this variation in the 'forces of production' is related to variations in way that 'mine-affected communities' are constructed as political entities in their own right and the way that 'localities' are to be defined in any assessment of local-level politics.

The entire population of Bougainville has come to be constructed as a single 'mine-affected community' because of the conflict that initially led to the closure of the Panguna mine and then escalated in the wake of that event, even if the customary owners of the mine lease areas still count as a more specific collection of political actors with a greater sense of grievance and entitlement (Chapter 12). Two-thirds of the population of PNG's Western Province has been officially recognised as a community or collection of communities affected by the operation of the Ok Tedi mine because of the scale of the environmental damage it has caused (Chapter 8). In contrast, the community affected by the Lihir project in New Ireland Province is generally defined - and certainly defines itselfas a much smaller collection of people with customary rights to land in the offshore group of islands where the mine is located (Chapters 10 and 11). And the communities affected by some of the mining projects in NC may be smaller still, comprising the resident populations of single communes or municipalities (Chapters 4, 5 and 6). But then again, as in the case of Bougainville, it could be argued that the whole of the Kanak population counts as one 'mine-affected community' because of the way that control of the mining industry has come to be defined as a focal point in their struggles for autonomy and independence. Furthermore, NC has 
the hallmarks of a single mining enclave or mineral province because of the density of the physical and social networks linking all of the actors in the local nickel industry, despite the segmentary form of local politics.

In our previous comparison between national jurisdictions, we were mainly concerned with the difference between (national-level) political institutions that have influenced or constrained the relationship between large-scale mines and local-level politics. This type of comparison bestows a measure of primacy on the 'state corner' in our rectangular model of stakeholder relationships, even when the relative 'power of the state' is understood to be something that varies from one jurisdiction to another. We are now moving in a rather different direction, where each mineral province is not only conceived as a sub-national level of political organisation, but also as a geographical space within which state actors have developed a distinctive set of political relationships with actors in the corporate, social and community corners. And at this juncture, we need to be wary of an ambiguity commonly found in academic discussion of the 'politics of scale', whereby scales and levels of political (or economic) organisation are not clearly differentiated because both are treated as artefacts of political (or economic) activity (Leitner et al. 2008; Huber and Emel 2009; Allen 2017).

Once this ambiguity is resolved, two additional dimensions can be added to the institutional dimension of difference in the politics of the mining industry. On one hand, there is a vertical or organisational dimension in which all four corners of our rectangular model, including the community corner, are internally stratified into levels or layers, so that some positions or roles are notionally 'higher up' than others. On the other hand, there is a horizontal or spatial dimension in which the four corners are also internally divided by the relative geographical proximity of different positions or roles to the project that constitutes the focal point of political activity. In both dimensions, there is room for variation in the number of political roles, and hence the number of political actors, in each of the four corners, including the number that belong to the 'local' level in an organisational hierarchy or the 'central' zone in a sort of spatial hierarchy.

The point of making this distinction is to understand the powers exercised by actors who occupy one position in the organisational dimension and another position in the spatial dimension. If we look at the corporate corner, for example, we commonly find that a multinational mining company's 'country manager', operating at the national level, typically has 
less power than the mine manager who operates at the local level. Both are separately accountable to the company's global or regional headquarters, but the country manager is typically responsible for the management of relationships with state actors who also operate at the national level, in the national capital, whereas the mine manager is responsible for the actual operation of the mine, as well as the management of relationships with mine-affected communities.

Even in the state corner, where the powers formally exercised by politicians and public servants commonly seem to be a function of their level of election or appointment, the powers that they actually exercise at a local level often turn out to be a function of their political and social connections to the place where a mining project is located. What this means is that the distance between the project and the capital of the mineral province in which it is located, let alone the national capital, generally turns out to be a critical variable in the exercise of state power. And in the community corner itself, where the emergence or elaboration of an organisational hierarchy often counts as one of the effects of a largescale mining project, there is no reason to assume that the actors who occupy the most senior positions will be those who occupy the innermost zone of maximal environmental impact. In other words, the practice of local-level politics may be partly motivated by a mismatch between the internal organisation of 'the community' - or its form of representationand the relative proximity of different groups of people to the site of the mining operation, or the degree of 'impact' that they experience as a result of it, or the types and amounts of benefits (or costs) that they derive from it.

The exercise of power in the practice of local-level politics is not simply a function of the position that an actor happens to occupy in one of the four corners of our rectangular model, or in one of the levels in an organisational hierarchy, or one of the concentric zones of impact or benefit, grievance or entitlement, that surround a specific mining project. As stated in the introduction to this volume, it is primarily revealed in the capacity of actors to engage in specific forms of action: to move from one corner to another, from one level to another, from one zone to another; to control, support or attack the movements of other actors between different positions; and to challenge or defend the legitimacy of the positions themselves, as well as the manner of their occupation. 
The history of mine-related political action in Bougainville (Chapter 12) presents us with an extreme case of the fluidity and complexity that can result from this exercise of power. The closure of the Panguna mine was not only accompanied by the evacuation of the corporate corner and the collapse of the organisational hierarchy of the provincial government, but also by the emergence of new (contested) hierarchies along the axis linking the community and social corners within the province. This in turn entailed the emergence of new (contested) distinctions between these two corners, and hence in the definition of who has how much of a claim to be part of the community affected either by the mine or by the conflict that engulfed it. While Anthony Regan argues that the social corner was barely occupied until foreign activists began to campaign against the reopening of the mine, it is clear from his own account that it was already occupied by the Christian churches and other organisations during the original campaign over the distributional issue. More recently, the state and corporate corners have been repopulated in new forms, but the distributional and representational issues are still deeply contentious.

The Ok Tedi mine was the second of PNG's mining projects to be designated as a project of 'national significance', but despite its size and the physical extent of its impact, this mine has acquired a form of locallevel politics that is quite unlike its counterpart in Bougainville. For one thing, there has been much greater interference by national-level state actors, partly to offset or reinforce the marginal role of the Fly River Provincial Government. Although this aspect of the balance of power within the state corner has not prevented the mining company or its corporate shareholders from performing a quasi-governmental role, the recent nationalisation of the mine has only served to make the company seem even more like a branch of the national government (Chapter 8). The consolidation of a multifunctional organisational hierarchy along this axis has been accompanied by a division of the mine-affected area into zones whose boundaries have been largely uncontested, and the communities contained within these zones are notable for the absence of organisational hierarchies in which positions of leadership or seniority are the subject of alternative forms of political contest. As a result, the organisational (and institutional) complexity that surrounds the operation of the mine and the management of 'community affairs' has no counterpart in a community corner that seems to be as 'flat' as it is 'wide' (Burton 1997). And despite the activation of the social corner during the (relatively brief) period when some community members were engaged in litigation against the mining 
company, this is a case that shows the absence of any correlation between the scale of a mining project and the amount of local-level politics that it generates. It is more like an extreme case of a mine that functions as an 'anti-politics machine' (Ferguson 1990).

The Koniambo project is the closest approximation to a project of national significance in NC, even if the nation in question is the one imagined by the Kanak nationalist movement. Its scale relative to the size and population of North Province is comparable to that of the Panguna and Ok Tedi mines in their respective provinces, but because it has only been developed over the course of the past decade, there remains a good deal of uncertainty about the direction in which the practice of locallevel politics is moving. In the planning and construction of the main processing plant, provincial state actors have played a mediating role between the corporate and community corners (Chapter 2), which is not unlike the role played by some national state actors in the original planning and construction of the Panguna and Ok Tedi projects during the 1960s and 1970s. This means that the risk of 'social disintegration' within the community corner has been addressed by the application of 'normative frameworks' generated at the provincial (state) level (Chapters 2 and 3). Nevertheless, these efforts have not been sufficient to conceal horizontal lines of political cleavage between zones of engagement (or entitlement) in the 'logic of proximity' to the processing plant, since community actors at the centre of the action appear to be less satisfied with the provincial solution to the distributional issue, and more inclined to support or oppose the project on the grounds of their 'traditional' political divisions (Chapter 3).

As previously noted, the factor that complicates the mediating role of (provincial) state actors in this context is the dual form of organisational hierarchy in which some of these actors occupy positions in the neotraditional political system as well as the formal system of electoral politics and bureaucratic administration. The split between chieftaincies and municipalities in the practice of local-level politics seems to have been less significant in the recent history of the Koniambo project than in the contest surrounding the closure and possible reopening of the Boakaine mine in the same province (Chapter 4). If this mine were to reopen, then it would be part of the network of relatively small mining operations that supply additional raw material to the Gwangyang plant in South Korea (Chapter 3), but its continued closure signals the presence of a barrier 
between the contested politics of the local community-the municipality and chieftaincies of Canala - and the entanglements of corporate and state actors operating at the level of North Province (Chapter 2).

If this form of political disengagement has been a function of the physical distance between the mine-affected community and the provincial capital, the same point would seem to apply to the neighbouring community of Thio in South Province (Chapter 5). In this case also, mining operations were disrupted by an episode of political conflict, yet the causes and consequences of that conflict were different because the practice of locallevel politics in this community has reflected the relative subordination and marginalisation of Kanak political actors in a different provincial context. In this case, the French company that 'traditionally' dominated the whole of the mining industry in NC was unable to maintain its customary practice of dealing privately with community protest, while community leaders deliberately made the conflict public as part of their demand for state actors to take more responsibility for validating their new deal with the company. However, this process itself has resulted in new forms of community engagement with actors operating in the social corner, whose actions tend now to be justified by reference to global, rather than provincial or national, normative frameworks.

These new forms of engagement are even more prominent in the politics of the Goro project, which is the second of the truly modern large-scale projects in NC, albeit one whose 'mine-affected community' is no larger than those attached to the medium-scale mining operations in Canala and Thio (Chapter 6). Here the social corner has been occupied by international and Caledonian non-governmental organisations (NGOs) concerned with environmental protection, operating in an unstable (and sometimes ruptured) alliance with community organisations and 'customary authorities' (Horowitz 2012). These actors have combined different forms of expression, protest and action, from the mobilisation of legal competencies and scientific counter-expertise to demonstration, blockage and a limited use of violence. While the NGOs have taken on some aspects of the mediating role played by provincial (state) actors in the organisation of the Koniambo project, their involvement has also created the opportunity for community actors to adopt a wider range of strategies and tactics in their own attempts to extract a 'sustainable development agreement' from the mining company (even if the company has since failed to uphold its own side of that bargain). 
On most counts, the Lihir project in PNG is bigger than both the Goro and Koniambo projects, but has never been officially designated as a project of national significance, and is isolated from the capital of its mineral province, not only in terms of physical distance but also by virtue of its location on a small island. The insularity of the mineaffected community has exercised a profound influence on the practice of local-level politics, in a manner that would no doubt be replicated if a large-scale mine were to be developed on one of the islands in NC's Loyalty Islands Province. While this community is internally divided by the strength of claims to ownership of the customary land leased to the mining company, and hence by a 'logic of proximity', it is also united by an ideology of landownership that denies membership of the community to anyone who lacks customary land rights in any part of the Lihir island group. While the status of the 'immigrant outsider' has become a political issue in the vicinity of other mining projects (Chapters 2 and 5), and was indeed one of the issues behind the eruption of the conflict that closed the Panguna mine (Chapter 12), this issue has taken on a peculiar form in the Lihirian context because of the way that such people have become the clients of 'landowner patrons' competing with each other for positions of seniority in the community's 'socioeconomic hierarchy' (Chapter 11). In effect, community leaders have reconstructed the social corner in our rectangular model to be one that is not occupied by 'civil society', but by members of a national society who have no formal rights to occupy any of the other three corners, and therefore constitute a rather different kind of nuisance.

The community-society axis has another kind of significance in this context, because of the way that the PNG Government has been persuaded (primarily by actors from the World Bank Group) to adopt the principle of 'gender mainstreaming' or 'gender equity' as a feature of its own mineral policy regime. This has created a space or corridor within the social corner through which a few Lihirian women have departed the shores of their island community in order to participate in national and global debates about the implementation of this policy. However, as Susan Hemer explains (in Chapter 10), this opportunity has been taken at the cost of their status and influence within a community in which men seek to maintain a 'customary' monopoly over the practice of local-level politics, and women can only be granted a form of authority if it is not 'political'. 


\section{Four-Wheel Drive?}

While a case can be made for limiting the definition of 'local-level politics' to the political practice that takes place within mine-affected communities and along the three channels of communication between community actors and actors in the other three corners of our rectangular model, the internal constitution of the other three corners, and the three distinctive channels of communication between them, can also have local dimensions and effects (Chapter 9). If the roles or positions assembled in each of these four corners constitute the political structure of the mining industry in a formal sense, the manner in which they are created and occupied is closely related to what we have called the representational issue, which is one of the two big issues on which our political actors act (Chapter 1). However, we can now see why the representational issue is somewhat less significant than the distributional issue, since the positions that our actors occupy can mostly be assigned to the organisational dimension of difference between the sites of their political activity. The distributional issue, by contrast, is a matter of substance with which they engage from positions in all three of the dimensions of difference that we have so far identified - not just the organisational dimension, but also the spatial and institutional dimensions.

This leads us to wonder whether there is a fourth dimension of difference or variation in the relationship between large-scale mines and local-level politics that could be just as significant. One obvious candidate would be the gender dimension, since it is widely recognised that big mining projects normally have a significant impact on gender relations in mineaffected communities (Lahiri-Dutt 2011). There is clearly a good deal of scope for variation between different projects, not only in the extent to which this impact has become a political issue for different groups of actors, but also in the consequences of the policies or activities by which it is addressed. The main reason that we have not treated this as the fourth dimension of difference in this volume is that only one of our contributors has dealt with the gendered nature of local-level politics in any detail (Chapter 10), so we do not have much additional light to cast on the difference between NC and PNG, or the variation between mining projects or mineral provinces, in this particular respect.

The second obvious candidate for recognition as a fourth dimension is the temporal dimension inherent in the concept of the mining 'project cycle' that leads from exploration to closure. The addition of this dimension 
is certainly consistent with our argument that what really counts in any analysis of local-level politics is the way that actors shift themselves and others from one position to another, since these forms of mobility have their own particular time scales. It might also be argued that the balance of power between different groups of actors_-and especially between the four corners of our rectangular model - tends to change over the different phases of the mining project cycle in ways that are independent of any particular institutional context (Chapter 2). This type of systematic shift has been ascribed to a form of 'capital logic' that applies to the relationship between large-scale mines and local-level politics in many different countries (Gerritsen and Macintyre 1991), and could therefore be seen as one aspect of the general process of modernisation and globalisation. The logic in question is one that operates around changes in the relationship between the costs borne or felt by mine-affected communities and the financial capacity of mining companies to compensate them in different phases of the project cycle (Howitt 2001). However, we would argue that the existence of three other dimensions of variation is precisely what makes it difficult for any group of actors to predict - and hence to managethe temporal transformations of power. Indeed, this is one of the main reasons why large-scale mining projects are subject to moments of rupture that come as a surprise to most of the actors who think they understand the local political trajectory. The forced closure of the Panguna mine is an obvious case in point (Chapter 12), but other contributions to this volume provide examples of 'nasty surprises' that disrupted the smooth passage of the mining project cycle (Chapters 4, 5 and 8 ). Whether or not these moment of rupture count as episodes of political conflict, the complexity of structural transformation is what enables actors to have the kind of agency that defies the power of management, and often leads to unintended and unwelcome outcomes.

\section{References}

Ali, S.H. and A.S. Grewal, 2006. 'The Ecology and Economy of Indigenous Resistance: Divergent Perspectives on Mining in New Caledonia.' Contemporary Pacific 18: 361-392.

Allen, M.G., 2017. 'Islands, Extraction and Violence: Mining and the Politics of Scale in Island Melanesia.' Political Geography 57: 81-90. dx.doi.org/10.1016/j.polgeo.2016.12.004 
Banks, G., 2008. 'Understanding "Resource" Conflicts in Papua New Guinea.' Asia Pacific Viewpoint 49: 23-34. doi.org/10.1111/j.14678373.2008.00358.x

Beck, U., 1992. Risk Society: Towards a New Modernity (transl. M. Ritter). London: Sage.

Burton, J., 1997. 'Terra Nugax and the Discovery Paradigm: How Ok Tedi Was Shaped by the Way It Was Found and How the Rise of Political Process in the North Fly Took the Company by Surprise.' In G. Banks and C. Ballard (eds), The Ok Tedi Settlement: Issues, Outcomes and Implications. Canberra: The Australian National University, National Centre for Development Studies (Pacific Policy Paper 27).

Clements, K., V. Boege, A. Brown, W. Foley and A. Nolan, 2007. 'State Building Reconsidered: The Role of Hybridity in the Formation of Political Order.' Political Science 59: 45-56. doi.org/ $10.1177 / 003231870705900106$

Collier, P. and A. Hoeffler, 2004. 'Greed and Grievance in Civil War.' Oxford Economic Papers 56: 563-595. doi.org/10.1093/oep/gpf064

Dean, M., 2010, Governmentality: Power and Rule in Modern Society (2nd edition). London: Sage.

Demmer, C. and C. Salomon, 2017. 'À Propos du Sénat Coutumier: De la Promotion Mélanésienne à la Défense des Droits Autochtones.' In C. Demmer and B. Trépied (eds), La Coutume Kanak dans l'État. Perspectives Coloniales et Postcoloniales sur la Nouvelle-Calédonie. Paris: L'Harmattan.

Dupuy, J.-P., 2002. Pour un Catastrophisme Eclairé: Quand l'Impossible est Certain. Paris: Seuil.

Ferguson, J., 1990. The Anti-Politics Machine: 'Development', Depoliticization, and Bureaucratic Power in Lesotho. Cambridge: Cambridge University Press.

Filer, C., 1997. 'Compensation, Rent and Power in Papua New Guinea.' In S. Toft (ed.), Compensation for Resource Development in Papua New Guinea. Boroko (PNG): Law Reform Commission (Monograph 6). Canberra: The Australian National University, National Centre for Development Studies (Pacific Policy Paper 24). 
Filer, C., M. Andrew, B.Y. Imbun, P. Jenkins and B.F. Sagir, 2016. 'Papua New Guinea: Jobs, Poverty, and Resources.' In G. Betcherman and M. Rama (eds), Jobs for Development: Challenges and Solutions in Different Country Settings. Oxford: Oxford University Press. doi.org/ 10.1093/acprof:oso/9780198754848.001.0001

Filer,C., J.BurtonandG. Banks, 2008. 'TheFragmentation of Responsibilities in the Melanesian Mining Sector.' In C. O'Faircheallaigh and S. Ali (eds), Earth Matters: Indigenous Peoples, the Extractive Industries and Corporate Social Responsibility. London: Greenleaf Publishing. doi.org/ 10.9774/GLEAF.978-1-909493-79-7_11

Gerritsen, R. and M. Macintyre, 1991. 'Dilemmas of Distribution: The Misima Gold Mine, Papua New Guinea.' In J. Connell and R. Howitt (eds), Mining and Indigenous Peoples in Australasia. Sydney: Sydney University Press.

Horowitz, L.S., 2012. 'Translation Alignment: Actor-Network Theory, Resistance, and the Power Dynamics of Alliance in New Caledonia.' Antipode 44: 806-827. doi.org/10.1111/j.1467-8330.2011.00926.x

Howitt, R., 2001. Rethinking Resource Management: Justice, Sustainability and Indigenous Peoples. London: Routledge.

Huber, M. and J. Emel, 2009. 'Fixed Minerals, Scalar Politics: The Weight of Scale in Conflicts over the "1872 Mining Law" in the United States.' Environment and Planning A 41: 371-388. doi.org/10.1068/a40166

Lahiri-Dutt, K. (ed.), 2011. Gendering the Field: Towards Sustainable Livelihoods for Mining Communities. Canberra: ANU E Press (AsiaPacific Environment Monograph 6).

Latour, B., 2005. Reassembling the Social: An Introduction to Actor-Network Theory. Oxford: Oxford University Press.

Le Meur, P.-Y., 2010. 'La Terre en Nouvelle-Calédonie: Pollution, Appartenance et Propriété Intellectuelle.' Multitudes 41: 91-98. doi.org/10.3917/mult.041.0091

__ 2017. 'Le Destin Commun en Nouvelle-Calédonie: Entre Projet National, Patrimoine Minier et Désarticulations Historiques.' Mouvements 91(3): 35-45. 
Leitner, H., E. Sheppard and K.M. Sziarto, 2008. 'The Spatialities of Contentious Politics.' Transactions of the Institute of British Geographers 33: 157-172. doi.org/10.1111/j.1475-5661.2008.00293.x

Ross, M., 2003. 'The Natural Resource Curse: How Wealth Can Make You Poor.' In I. Bannon and P. Collier (eds), Natural Resources and Violent Conflict: Options and Actions. Washington (DC): World Bank.

Szablowski, D., 2007. Transnational Law and Local Struggles: Mining Communities and the World Bank. Portland (OR): Hart Publishing.

Walker, G., 2012. Environmental Justice: Concepts, Evidence and Politics. London: Routledge. 
This text is taken from Large-scale Mines and Local-level Politics: Between New Caledonia and Papua New Guinea, edited by Colin Filer and Pierre-Yves Le Meur, published 2017 by ANU Press, The Australian National University, Canberra, Australia. 